\title{
Phytochemical Screening and Proximate Composition of Aqueous-Methanol Pulp Extract of Azanza garckeana (Goron Tula)
}

* ${ }^{1}$ Momodu, I.B., ${ }^{2}$ Agoreyo, B.O., ${ }^{3}$ Okungbowa, E.S., ${ }^{4}$ Igiebor, S. E. and ${ }^{5}$ Igbo, I.O.L 1,2,3,4,5 Department of Biochemistry, Faculty of Life Sciences, University of Benin, P.M.B. 1154, Benin City, Edo State, Nigeria.

Email: idris.momodu@lifesci.uniben.edu

\begin{abstract}
Azanza garckeana is a shrub and tropical fruit-bearing tree. It belongs to the malvaeceas family and has spherical woolly edible fruits. In this study, qualitative phytochemical screening, proximate analysis and evaluation of minerals were carried out on the aqueous-methanol pulp extract of Azanza garckeana fruit (Goron Tula). The presence of saponins, alkaloids and phenol were detected. The proximate analysis revealed the presence of moisture $(10.90 \pm 0.40 \%)$, Dry matter $(89.10 \pm 0.40 \%)$, ash $(4.51 \pm 0.40 \%)$, fibre $(0.94 \pm 0.13 \%)$, fat $(3.16 \pm 0.00 \%)$, crude protein $(6.43 \pm 0.29 \%)$ and nitrogen-free substances (74.06 $\pm 0.24 \%)$. Evaluation of essential minerals revealed the presence of $\mathrm{Ca}(386.83 \pm 0.63 \mathrm{mg} / \mathrm{kg}), \mathrm{Mg}(205.27 \mathrm{mg} / \mathrm{kg} \pm 0.46), \mathrm{Na}(9.70 \mathrm{mg} / \mathrm{kg} \pm 0.06), \mathrm{K}(774.17 \mathrm{mg} / \mathrm{kg} \pm$ 0.07), Fe (28.49 $\mathrm{mg} / \mathrm{kg} \pm 0.38), \mathrm{Zn}(19.92 \mathrm{mg} / \mathrm{kg} \pm 0.41)$ and $P(161.62 \mathrm{mg} / \mathrm{kg} \pm 0.25)$. The result shows that the aqueous-methanol pulp extract of Azanza garckeana (Goron Tula) contain phytochemicals, proximate composition, as well as high mineral content, which may give credence to it medicinal and dietary uses.
\end{abstract}

Keywords: Azanza garckeana, goron-tula, Aqueous-methanol Extract, Phytochemicals, Proximate analysis.

\section{INTRODUCTION}

Chemical substances abound in several medicinal plants that are known as phytochemicals. Several of which have been shown to possess therapeutic potentials that could be harnessed for curative purpose (Sherif et al., 2017; Saxena et al., 2013). One very important preliminary stride in the exploration of phytochemical present in plants is phytochemical screening. The identification of these phytochemical paves way for the isolation and characterization of novel compounds with promising biological potentials (Obayuwana, et al., 2020). Proximate composition analysis is the determination of a group of closely related compounds in a substance such as plants. These closely related components are usually classified as moisture, ash, crude protein, crude lipid, crude fibre, and nitrogen free extracts. The analysis and study of proximate composition is essential in understanding the nutritional composition of a plant (Ilodibia, et al., 2014). 
Azanza garckeana, which is commonly called 'goron tula' in northern Nigeria belongs to the plant family malvaeceae. Azanza garckeana tree is a shrub that grows to a height between 3 to $15 \mathrm{~m}$. It is distributed within West, South, East and Central Africa. This plant is consumed locally within its distribution range as food. It is also known and use for curative purposes. The ripened fruits of Azanza garckeana are used as remedy for anemia, menstrual problem, infertility, as well as sexually transmitted infection such as gonorrhea in Nigeria and Botswana (Maroy, 2017). The ripened fruit is also eaten as a form of stimulant for sexual desire (aphrodisiac) (Dikko et al., 2016). Similarly, extracts from root, leaf, stem, as well as ripened fruits of Azanza garckeana are use as treatment for infertility related issues and liver diseases in Kenya and Malawi (Dikko et al., 2016; Ochokwu et al., 2015). The ripened fruit are also taken for anemia in Sudan and the root of Azanza garckeana tree are used to instigate labor in pregnant women in Tanzania (Maroy, 2017). The evaluation of the phytochemical constituent, as well as mineral composition of the pulverized pulp of the fruits have being previously reported. It revealed the presence of alkaloids, tannins, flavonoids, and saponins (Nkafamiya et al., 2016; Jacob et al., 2016). The presence of calcium (Ca), cobalt (Co), copper $(\mathrm{Cu})$, iron $(\mathrm{Fe})$, magnesium $(\mathrm{Mg})$, manganese $(\mathrm{Mn})$, phosphorus $(\mathrm{P})$ and zinc $(\mathrm{Zn})$ have also been reportedly found in the pulverized pulp of the fruit of Azanza garckeana fruit (Nkafamiya et al., 2016). However, as a prelude to further study of evaluating the effect of aqueous-methanol pulp extract of the fruit of Azanza garckeana using animal model. This study was carried out to determine the chemical constituent present in the pulp of the fruit, as well as the proximate composition and essential minerals present when extracted using a combination of aqueous and methanol solvent. This will enable us corroborates our future findings to the constituents extracted from the pulverized pulp using a combination of aqueous-methanol solvent.

\section{METHODOLOGY}

\section{Collection and identification of plant materials}

The fruits and fresh leaves of Azanza garckeana were procure from Tula Wange in Kaltungo Local Government Area (LGA) of Gombe State, North-eastern Nigeria on the 26th of September 2019. Identification and authentication of the plant parts were carried out at the Forest Research Institute of Nigeria (FRIN) in Ibadan and Herbarium voucher specimen with registration number FHI-112621 was placed in its citation.

\section{Preparation of pulp extract of Azanza garckeana}

The pulp of Azanza garckeana fruits were segregate from the seeds and dried in the oven at 60 ${ }^{\circ} \mathrm{C}$. They were pulverised (plate 2) after drying and immersed in $80 \%$ methanol and $20 \%$ water (v/v) for 72 hours, stirring everyday. The mixture was filtered after 72 hours using a muslin cloth. The filtrate was condensed using a rotary evaporator set at $60{ }^{\circ} \mathrm{C}$ to take out the methanol, and then lyophilized. Prior to use, the aqueous-methanol pulp extract was kept in the refrigerator at $4{ }^{\circ} \mathrm{C}$. 


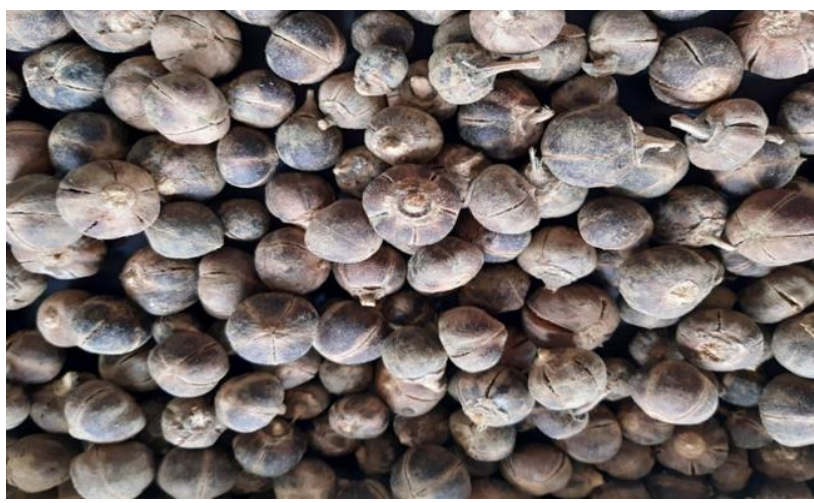

Plate 1: Fruits of Azanza garckeana



Plate 2: Pulverizing pulp using mortar and pestle

\section{Phytochemical screening}

Phytochemicals present in the extract were screened for using standard methods.

Test for Alkaloids: Aliquot of $1 \mathrm{~mL}$ of $1 \% \mathrm{HCl}$ was added to $3 \mathrm{~mL}$ of extract in a test tube. After heating for 20 minutes, cooling followed and then the mixture was filtered. To $1 \mathrm{ml}$ of the filtrate, 2 drops of Mayer's reagent was appended. The formation of whitish or creamy precipitate was used to confirm the presence of alkaloids (Trease and Evans, 2002).

Test for Flavonoids (Alkaline reagent tests): A few drops of sodium hydroxide solution were used to treat a $2 \mathrm{~mL}$ test solution, which resulted in a strong yellow color that vanished when dilute hydrochloric acid $(\mathrm{HCl})$ was added. This observation was an indication of flavonoids presence (Sofowora, 1993).

Test for Phenols (Ferric Chloride Test): The aqueous-methanol pulp extract was dissolved in alcoholic solution. Exactly $1 \mathrm{~mL}$ of distilled water was placed in to $5 \mathrm{~mL}$ of extract alcoholic solution, followed by drops of $10 \%$ aqueous ferric chloride $\left(\mathrm{FeCl}_{3}\right)$ solution. The presence of phenols was demonstrated by the production of a blue coloration.

Test for Saponins (Frothing Test): Exactly 10mL of distilled water was used to dissolve $3 \mathrm{ml}$ of the aqueous solution of the plant extract in a test tube and quiver vigorously for $5 \mathrm{~min}$. Frothing appearance was taken as a preliminary indication of saponins presence. To an aliquot of $1 \mathrm{~mL}$ of the extract, few drops of olive oil also were added and vigorously shaken. Soluble emulsion formation in the extract confirms the presence of saponin.

Test for Tannins: A test solution containing $15 \%$ ferric chloride was used to treat the aqueous-methanol pulp extract of Azanza garckeana, with a resulting blue color observed. This blue colouration indicates the presence of hydrolysable tannin. A dirty precipitate observed from dissolving $1 \mathrm{~mL}$ of the extract in $5 \mathrm{~mL}$ solution of a freshly prepared $\mathrm{KOH}$, confirms the presence of tannin.

\section{Proximate analysis}

The investigation of the proximate composition of the plant extract to determine the Moisture Content, Dry matter, Ash, Fat, Fibre, Protein, and Nitrogen free extract (NIFE) was carried out in accordance with the Association of Official Analytical Chemists (AOAC, 2000) technique. 


\section{Determination of some essential minerals; $\mathrm{Ca}, \mathrm{Mg}, \mathrm{Na}, \mathrm{K}, \mathrm{Fe}, \mathrm{Zn}$ and $\mathrm{P}$}

Atomic absorption spectrophotometer (UNICAM Model SOLAAR 969) was use in the ascertainment of mineral content of calcium (Ca), magnesium $(\mathrm{Mg})$, iron $(\mathrm{Fe})$ and zinc $(\mathrm{Z})$. Flame Photometer was used to determine that of sodium (Na), potassium (K) and Spectrometer (model: Spectronic 20D+) for phosphorus (P) following the technique described by the AOAC for the wet digestion of samples.

Using a digestion flask, exactly $1.0 \mathrm{~g}$ of the sample was placed, with an aliquot of $12 \mathrm{~mL}$ concentrated $\mathrm{HNO}_{3}$ added and kept for twenty-four (24) hours at room temperature. After which, $4.0 \mathrm{~mL}$ of $\mathrm{HClO}_{4}$ was appended to the mixture and heated, starting at $50{ }^{\circ} \mathrm{C}$ with a gradual increase up to $250{ }^{\circ} \mathrm{C}$. Digestion completion was indicated by the advent of fumes at 70-80 min. The mixture was allowed to cool; after which they were transferring into a 100 $\mathrm{mL}$ volumetric flask. Thereafter made to the $100 \mathrm{~mL}$ mark with distilled water. The digested solution was kept in a plastic reagent vial and used in mineral analysis (Gul and Safdar, 2009).

\section{Statistical Analysis}

Data were subjected to statistical analysis using one-way analysis of variance (ANOVA) (SPSS 25). All values are expressed as mean \pm standard error of mean (SEM).

\section{RESULTS}

The phytochemicals present in the aqueous-methanol pulp extract of Azanza garckeana are shown in Table 1. The result reveals the presences of alkaloid, phenols and saponin. The phenols content was found to be moderately high, while that of alkaloid and saponins were trace amounts. Proximate and mineral analysis result of the aqueous-methanol pulp extract of Azanza garckeana fruits are shown in Table 2 and 3 respectively. Proximate analysis (Table 2) revealed that pulp extract of Azanza garckeana fruits contains moisture, dry matter, ash, crude fat, crude fiber, protein, and nitrogen free extracts (NIFE) in varying proportion. The determination of essential minerals in the extract revealed the presence of potassium $(\mathrm{K})$, calcium $(\mathrm{Ca})$, phosphorus $(\mathrm{P})$, iron $(\mathrm{Fe})$, zinc $(\mathrm{Zn})$, magnesium $(\mathrm{Mg})$ and sodium $(\mathrm{Na})$ in varying proportion (Table 3 ).

Table1: Phytochemical constituent of the pulp extract of Azanza garckeana fruit Phytochemicals

\begin{tabular}{lc} 
Alkaloids & + \\
Flavonoids & - \\
Phenols & ++ \\
Saponins & + \\
Tannins & - \\
\multicolumn{1}{l}{ Key: $+++=$ High $;++=$ moderately high; + = Trace amounts; - = Not detected }
\end{tabular}

Table 2: Proximate analysis content of the pulp extract of Azanza garckeana fruit

\begin{tabular}{ll}
\hline Proximate & $\mathbf{( \% )}$ \\
\hline Moisture content & $10.90 \pm 0.40$ \\
Dry matter & $89.10 \pm 0.40$ \\
Ash & $4.51 \pm 0.40$ \\
Crude fat & $3.16 \pm 0.00$ \\
Crude fiber & $0.94 \pm 0.13$ \\
Protein & $6.43 \pm 0.29$ \\
NIFE & $74.06 \pm 0.24$ \\
\hline
\end{tabular}


Data are express as mean \pm SEM of three replicates, $n=3$

Table 3: Essential mineral content of the pulp extract of Azanza garckeana fruit

\begin{tabular}{lc}
\hline Essential Mineral & $\mathbf{( m g / k g )}$ \\
\hline Potassium (K) & $774.17 \pm 0.07$ \\
Calcium (Ca) & $386.83 \pm 0.63$ \\
Phosphorus (P) & $161.62 \pm 0.25$ \\
Iron (Fe) & $28.49 \pm 0.38$ \\
Zinc (Zn) & $19.92 \pm 0.41$ \\
Magnesium (Mg) & $205.27 \pm 0.46$ \\
Sodium (Na) & $9.70 \pm 0.06$
\end{tabular}

Data are express as mean \pm SEM of three replicates, $n=3$

\section{DISCUSSION}

\section{Phytochemical Screening}

Phytochemicals are termed as non-nutrient plant component and are present in various plant parts such as its fruits, leaves, stem and roots. The consumption of medicinal plants with certain phytochemicals have been correlated with decline in the risk of several major chronic illnesses (Saxena et al., 2013). In this study, qualitative screening for the presences of phytochemical was performed on the pulp extract of Azanza garckeana fruit. The result revealed the presences of alkaloid, phenols and saponins in the pulp extract of Azanza garckeana fruit. Alkaloids have stimulating effect, they are used as tropical anesthetic in ophthalmology and also as pain reliever (Usunobun et al., 2014). Alkaloids are reported to have antibacterial property as well (Usunobun et al., 2014). Hence, Alkaloid presences in the pulp extract may be responsible for anti-bacterial activity that has been reported for Azanza garckeana fruit (Bioltif et al., 2020). The other phytochemicals confirmed to be present in the extract are phenols and saponins. Azanza garckeana' antibacterial action may also potentially be due to the presence of phenolic compounds (Ofokansi et al., 2005). Saponins possess antioxidant effects on the skin and protect it against UV damage. It inhibits cancerous cell growth, strengthen immune system, lowers cholesterol levels, antibiotic and help in the maintenance of membrane integrity (Ojezele et al., 2016; Aberoumand 2012).

Proximate analysis content of pulp extract of Azanza garckeana fruit

The result of the proximate analysis of the pulp extract of Azanza garckeana fruit obtained shows the extract contains moisture, dry matter, ash, crude fat, crude fiber, protein, and nitrogen free extracts (NIFE) in varying proportion. The pulp has a low moisture content of $10.90 \pm 0.40 \%$ and plant with a low moisture content is easier to preserve (Umar et al., 2011). The mineral content of a substance in the biota is reflective on its Ash content (Olude et al., 2020), the ash content in the extract of Azanza garckeana was $4.51 \pm 0.40 \%$ indicating that the pulp contains minerals and more organic components. Dietary fats serve as energy source, aid in the absorption of fat soluble vitamins (Vitamin A, D, E and K), required for growth, immunological roles and reproduction. However, elevated intake of fats is correlative with obesity and heart related diseases (Olude et al., 2020). The pulp extract contains low crude fat $(3.16 \pm 0.00 \%)$, which is however higher than those reported for the pulverized fruit of Azanza garckeana (Jacob et al., 2016). Crude fibers are not digestible in humans but they aid in digestion. The crude fiber content in the pulp extract is relatively low at $0.94 \pm 0.13 \%$.

Mineral content of the pulp extract of Azanza garckeana fruit

The determination of essential minerals in the extract revealed the presence potassium $(\mathrm{K})$, calcium $(\mathrm{Ca})$, phosphorus $(\mathrm{P})$, iron $(\mathrm{Fe})$, zinc $(\mathrm{Zn})$, magnesium $(\mathrm{Mg})$ and sodium $(\mathrm{Na})$ in 
varying proportion. Potassium $(\mathrm{K})$ and Calcium $(\mathrm{Ca})$ were found to be the highest with 774 and $398 \mathrm{mg} / \mathrm{kg}$ of the extract, while sodium $(\mathrm{Na})$ was found to be the least.

The mineral's potassium $(\mathrm{K})$ and calcium $(\mathrm{Ca})$ play important role in stimulating action potential across nerve endings. Calcium is central to blood clotting, muscle contraction, hormonal regulation, as well as a major component of bone and teeth development (Olude et al., 2020). In addition, the skeletal system requires calcium and phosphorus for growth and maintenance. They also play a part in some physiological processes and play chief role in muscle contraction, blood clotting formation, maintenance of cell integrity, acid-base equilibrium, and the activation of several important enzymes.

Nucleic acids contain phosphorus as an essential component of the phosphate end and the polar head of cell membrane phospholipids. Phosphorus is directly required in virtually all energy-yielding cellular processes (Omotosho et al., 2018). Iron (Fe) is physiologically required for the formation of heme, leading to hemoglobin formation, whose deficiency causes anaemia (Ogbeide et al., 2020). Magnesium, iron and zinc are important co-factors in several metabolic reactions such as oxidative phosphorylation, glycolysis and protein digestion (Usunobun and Okolie, 2015; Ogbeide et al., 2020).

\section{CONCLUSION}

Phytochemicals, proximate and mineral contents of the pulp extract of Azanza garckeana implies that it can be utilized for medicinal and dietary purpose.

\section{REFERENCES}

Aberoumand, A. (2012). Screening of phytochemical compounds and toxic proteinaceous inhibitor in some lesser-known food based plants and their effects and potential applications in food. International Journal of Food Science and Nutrition Engineering, 2(3): $16-20$.

AOAC (Association of Official Analytical Chemists). (2000). Official method of analysis. 15th Edition, Washington D.C. p212.

Bioltif, Y. N., Edward, N. B. and Tyeng, T. D. (2020). A chemical overview of Azanza garckeana. Biology Medicine and Natural Product Chemistry, Vol: 9(2): 91-95. DOI: 10.14421/biomedich.2020.92.91-95.

Dikko, Y. J., Khan, M. E., Tor-Anyiin, T. A., Anyam, J. V. and Linus, U. A. (2016). In vitro antimicrobial activity of fruit pulp extracts of Azanza garckeana (F. Hoffm.) Exell and Hillc. and isolation of one of its active principles, Betulinic acid. British Journal of Pharmaceutical Research, 14: 1-10.

Gul, S. and Safdar, M. (2009). Proximate composition and mineral analysis of cinnamon. Pakistan journal of nutrition, 8(9): 1456-1460.

Ilodibia, C. V., Ugwu, R. U., Okeke, C. U., Ezeabara, C. A. and Okeke, N. F. (2014). Determination of proximate composition of various parts of two Dracaena species. International Journal of Botany, 10(1): 37-41.

Jacob, C., Shehu, C., Danbature, W. L. and Karu, E. (2016). Proximate analysis of the fruit of Azanza garckeana. Bayero Journal of Pure and Applied Science, Vol. 9(2): 221-224.

Maroy, A. (2017). Azanza garckeana fruit tree: phytochemistry, pharmacology, nutritional and primary healthcare applications as herbal medicines: A review. Research Journal of Medicinal Plants, 11(4): 115-123. 
Nkafamiya, I. I., Ardo, B. P., Osemeahon, S. A. and Akinterinwa, A. (2016). Evaluation of nutritional, non-nutritional, elemental content and amino acid profile of Azanza garckeana (Goron Tula). British Journal of Applied Science and Technology, 12(6): 1-10.

Obayuwana, O., Imafidon, K. E. and Abu, O. D. (2020). Phytochemical and proximate composition of leaves of Anarcadium occidental. IAR Journal Agriculture Research Life Sciences, Vol 1(5): 139-142.

Ochokwu, I. J., Dasuki, A. and Oshoke, J. O. (2015). Azanza garckeana (goron tula) as an edible indigenous fruit in north eastern part of Nigeria. Journal of Biology, Agriculture and Healthcare, 5: 26-31.

Ofokansi, K. C., Esinone, C. O. and Anele, C. K. (2005). Evaluation of the leaf extracts of Bryophyllum pinnatum (Fam. Crassulaceae) and Ocimum gratissimum (Fam.Labiatae). Plant Production Research Journal, 9: 23 - 27.

Ogbeide, O. K., Okhomina, O. K, Omoregie, I. G., Unuigbe, C. A., Ighodaro, A. et al. (2020). Antimalarial, ferric reducing antioxidant power and elementary analysis of Caesalpinia pulcherrima leaf extract. Journal of Chemical Society of Nigeria, 45(4):704-711.

Ojezele, O. J., Ojezele, M.O. and Adeosun, A. M. (2016). Comparative Phytochemistry and Antioxidant Activities of Water and Ethanol Extract of Annona muricata Linn Leaf, Seed and Fruit. Advances in Biology Research, 10(4):230-235.

Olude, O. M., Asoya, V. E. and Uchenna, H. I. (2020). Phytochemical and Nutritional Composition of Crude Powder and Ethanol Extract of Annona muricata Leaves. Tropical Journal of Natural Product Research, 4(7):315-318. doi.org/10.26538/tjnpr/v4i7.11

Omotosho, O. E., Iheagwam, F. N., Noiki, I. A. and Omini J. J. (2018). Comparative Study on Chemical Composition and Antioxidant Activity of Annona muricata Plant Parts Cultivated in Covenant University, Ota, Ogun State, Nigeria. Current Research in Nutrition and Food Science. 6(3):807-815.

Saxena, M., Saxena, J., Nema, R., Singh, D. and Gupta, A. (2013). Phytochemistry of Medicinal Plants. Journal of Pharmacognosy and Phytochemistry, 1(6):169-182.

Sherif, H. B., Baba, G. and Abdullahi, S. M. (2017). Acute and Sub-Chronic Toxicity Profile of Annona muricata (Soursop) on Wistar Albino Rats. Bayero Journal of Pure and Applied Science, 10(2):57-63.

Sofowora, A.O. (1993). Medicinal Plants and Traditional Medicine in Africa. 2nd ed. University of Ife Press. Pp 320.

Trease, G.E. and Evans, W.C. (2002). Phytochemicals. In: Pharmacognosy, Saunders Publishers, London.

Umar, A., Jimoh, W.L.O. and Garba, M. D. (2011). Proximate analysis of Lepidium sativum leaves. Chemsearch Journal, 2(1): 26-27.

Usunobun, U. and Okolie, N. P. (2015). Phytochemical analysis and mineral composition of Annona muricata leaves. International Journal of Research and Current Development, $1(1): 38-42$

Usunobun, U., Okolie, N. P., Anyanwu, O. G. and Adegbegi, A. J. (2014). Phytochemical Screening and Proximate Composition of Annona muricata Leaves. European Journal of Botany Plaint Science and Phytology, 2(1):18-28. 